\title{
Byssinosis, respiratory symptoms and spirometric lung function tests in Tanzanian sisal workers
}

\author{
K. Y. MUSTAFA ${ }^{1 *}$, A. S. LAKHA ${ }^{2}$, M. H. MILlA ${ }^{3}$, AND U. DAHOMA \\ From the ${ }^{1}$ Faculty of Medicine, University of Dar es Salaam, and the ${ }^{2,3,4}$ Preventive Department, \\ Ministry of Health, Tanzania
}

ABSTRACT Byssinosis and other respiratory symptoms and acute and chronic changes in FVC and $\mathrm{FEV}_{1 \cdot 0}$ were investigated in 77 workers in sisal spinning and 83 workers in sisal brushing departments in six Tanzanian sisal factories. Although the prevalence of byssinosis in spinning departments was found to be low $(5 \cdot 2 \%)$, it was very high in brushing departments $(48 \cdot 2 \%)$. Workers in brushing were exposed to sisal dust for a significantly longer period (11.77 $\pm 7 \cdot 3$ years) compared to workers exposed to sisal in spinning $(2.85 \pm 2.56$ years). Although the number of smokers in brushing $(42 \%)$ was similar to that in spinning $(37 \%)$, smokers were more prone to byssinosis than were non- or ex-smokers after standardisation for duration of exposure. We were unable to measure dust levels in this study, but dust levels in spinning and brushing are cited from previous studies. These confirm our impression that the dust level in spinning is higher than that in an average cotton carding department and far higher in brushing than in spinning. Acute falls in FVC and FEV 1.0 were found during the work shift. The extent of the fall in $\mathrm{FEV}_{1 \cdot 0}$ correlated well with the severity of byssinosis; $75 \%$ of the workers with grade II byssinosis and $33 \%$ of those with grade $\frac{1}{2}+$ I were found to have acute falls in $\mathrm{FEV}_{1.0}$ greater than 0.2 litres. However some workers, $10 \%$ in spinning and $33 \%$ in brushing, who denied symptoms of byssinosis, were also found to have acute falls in FEV 1.0. Some workers had slight or severe chronic ventilatory impairment from dust (FEV 1.0 $^{\circ}$ less than $80 \%$, or less than $60 \%$ of the respective predicted values), and these workers were mostly from the brushing department. The prevalence of chronic cough and chronic bronchitis was found to be negligible in workers in the spinning and in the brushing departments: $9.6 \%$ had a chronic cough and $12 \%$ had chronic bronchitis. It is concluded that a high prevalence of byssinosis associated with chronic and acute changes in FVC and FEV 1.0 occurs in the brushing departments of sisal factories, and that this is related to lengthy exposure, high dust level and smoking.

The prevalence of byssinosis has been well documented in European cotton workers (Schilling, 1956; Lammers et al., 1964) and in African workers (El Batawi et al., 1964; Khogali, 1969). It has also been described in flax and soft hemp workers (Smiley, 1961; Bouhuys et al., 1967). Mair et al. (1960) and Gandevia and Milne (1965) found no evidence of byssinosis in jute workers. Relatively few studies have been carried out on sisal which is another hard vegetable fibre. Stott (1958) and Gilson et al. (1962) studied Kenyan workers in a sisal twine and rope factory on two separate occasions

*Correspondence to Khatim Y. Mustafa, Faculty of Medicine, P.O. Box 5969, Kuwait

Received for publication 26 July 1977

Accepted for publication 12 August 1977 and found no symptoms of byssinosis and only a small fall in ventilatory capacity during a work shift. In a rope factory using sisal, McKerrow et al. (1965) found a significant fall in forced vital capacity (FVC) and forced expiratory volume in one second $\left(F V_{1 \cdot 0}\right)$ during the shift but no symptoms of byssinosis.

These studies on sisal workers included small numbers of workers exposed only briefly and were all in twine spinning or rope factories. The only study on a brushing department in sisal estates (Stott, 1958) did not cover symptoms of byssinosis or ventilatory function tests. This process is an early stage in sisal preparation before it is sent to the twine and rope factories.

Because the sisal industry is vital to the economy of Tanzania we decided to study more workers in the spinning departments in twine and rope fac- 
tories, and to extend the investigation to workers in the brushing section of sisal estates.

The area selected for this study was the Tanga region, in northern Tanzania, which is one of the largest centres for the sisal industry in the world. All sisal factories within a radius of $\mathbf{3 0}$ kilometres of Tanga were studied: there were six altogether, three spinning and three brushing sisal. Thirty workers, from the morning shifts only (6 am-2 pm) were randomly selected from each factory. Thirteen of the 90 workers selected from sisal spinning were not seen, so that the 77 workers examined represented $75 \%$ of the workers in those departments. Seven of the 90 workers selected from brushing were not seen, and the 83 workers studied represented $90 \%$ of the workers in the brushing departments. Those who were not seen were either absent or refused to co-operate.

\section{DESCRIPTION OF FACTORIES}

In the sisal estates, sisal fibres are separated from the leaves by wet retting, a process called decortication. In this section the workers are not exposed to any dust. The fibres are then dried in the sun, and taken inside to the brushing department. Here bundles of long sisal fibres are fed by hand into brushing machines. The fibres are manually and repeatedly pushed in and out of the machines where they are softened, cleaned and combed; then the fibres are withdrawn and put aside ready for baling. The outside workers remove the dust from the brushing machines and separate from it the useful long fibres which escape to the outside during brushing. The workers interchange between the inside and outside work-place. The only ventilation is natural.

The processes in sisal twine and rope factories were described by Gilson et al. (1962) and are basically similar to bale opening, carding and spinning in cotton textile factories. The workers studied were from carding and spinning departments.

\section{Methods}

On a first visit the workers completed the Medical Research Council Questionnaire on respiratory symptoms (1960) with additional questions on chest tightness (Roach and Schilling, 1960) translated into Kiswahili. The questionnaire was modified in the following ways:

1. The phrase 'in the winter' was substituted by a Kiswahili phrase meaning 'during time of cold' as the season winter is not recognised.

2. The section on tobacco smoking was extended to cover local tobacco smoking.

3. The section on dusty occupations was altered to cover cotton, sugar, sisal, mouldy hay and mouldy grain.

\section{DEFINITIONS}

\section{Chronic cough and/or phlegm}

Cough and/or phlegm production on most days for at least three months per year.

\section{Chronic bronchitis}

Cough and phlegm for a minimum of three months in the year for not less than two successive years.

\section{Byssinosis}

Grade $\mathbf{0}=$ No symptoms of byssinosis.

Grade $\frac{1}{2}=$ Occasional chest tightness or difficulty in breathing on the first day of the work shift.

Grade $\mathbf{I}=$ Chest tightness or difficulty in breathing on the first day of every work shift.

Grade II = Chest tightness or difficulty in breathing on the first day and other days of the work shift.

The ventilatory function test procedure was carefully explained and demonstrated to the workers, each of whom was given a chance to practice. Thirty workers repeatedly failed to perform the test in the practice sessions and were excluded. FVC and FEV 1.0 were measured with a dry wedge spirometer in the standing position and the mean of the two highest attempts of five trials was taken. The tests were performed between 6 am and 7 am on the first day of the shift after the two days off before entering the factory (pre-shift) and at the end of the shift between $2 \mathrm{pm}$ and $3 \mathrm{pm}$ (after-shift). The acute changes in FVC $(\triangle F V C)$ and in $F^{2} V_{1 \cdot 0}$ $\left(\triangle F_{E V} \cdot 0\right)$ were then calculated. All readings were corrected to ATPS $20^{\circ} \mathrm{C}$. Predicted normal values of FVC and FEV ${ }_{1.0}$ were obtained by substituting the mean age and height in the following multiple linear regression equations:

$$
\begin{aligned}
F V C & =0.064 \mathrm{H}_{\mathrm{cm}}-0.016 \mathrm{~A}-6.14 \\
\mathrm{FEV}_{1.0} & =0.046 \mathrm{H}_{\mathrm{cm}}-0.022 \mathrm{~A}-3.864
\end{aligned}
$$

These equations were found accurately to predict FVC and FEV $_{1.0}$ in normal Tanzanian adult males (Mustafa, 1977). During a working day the workers were called one by one for a clinical examination during which the standing height was measured.

\section{Results}

Table 1 shows the prevalence of byssinosis, chronic cough and/or phlegm and chronic bronchitis in spinning and brushing departments. In spinning departments symptoms of byssinosis were found in 4 workers $(5 \cdot 2 \%)$. By contrast a very high prevalence of byssinosis was found in $40(48 \%)$ workers in brushing departments, $50 \%$ of whom had 
Table 1 Prevalence of byssinosis and respiratory symptoms in sisal workers in spinning and brushing departments

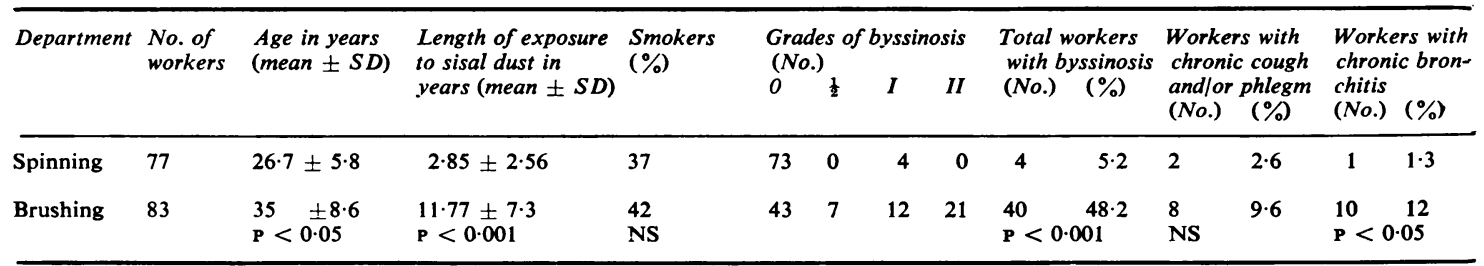

grade II byssinosis. The prevalence of chronic cough and chronic bronchitis was negligible in spinning, and $9.6 \%$ and $12 \%$ respectively in brushing. The mean age was significantly higher for the workers in the brushing department compared with that of workers engaged in spinning $(35 \pm 8.6$ years versus $26.7 \pm 5.8$ years; $P<0.05)$. The duration of exposure was also significantly longer in workers in the brushing department compared with those in spinning $(11.77 \pm 7.3$ years versus $2.85 \pm 2.56$ years; $P<0.001)$. No significant difference was observed in the smoking habits: $42 \%$ of brushing workers smoked compared with $37 \%$ in spinning. More than $90 \%$ of smokers in both departments smoked less than 10 cigarettes per day. None of the subjects in the study smoked local tobacco.

Table 2 shows the relationship of prevalence of byssinosis to smoking habit and duration of exposure for workers in the brushing department. For both smokers and non- or ex-smokers the prevalence of byssinosis increased with duration of exposure. It can also be seen that for any duration of exposure the prevalence is higher for smokers than for non- or ex-smokers. The results were not standardised for age.

FVC AND FEV1.0

Table 3 shows the mean observed pre-shift and after-shift values of FVC and $F E V_{1} \cdot 0$ together with the acute changes in these variables during the shift expressed as a percentage of the pre-shift values in workers without byssinosis, and in brushing workers with grade $\frac{1}{2}+$ I and grade II byssinosis. It can be seen that exposure to dust led to a small acute fall in FVC and FEV F. $_{1.0}$ in workers without byssinosis and with byssinosis grade $\frac{1}{2}+\mathrm{I}$, but greater falls in workers with grade II byssinosis, comprising a $6 \%$ fall in FVC and a $15 \%$ fall in $\mathrm{FEV}_{1 \cdot 0}$. The only statistically significant acute change is in the FEV 1.0 of grade II byssinosis.

The acute changes in $\mathrm{FEV}_{1.0}$ during dust exposure were further analysed (Table 4) according to the grading system of Bouhuys et al. (1970). A fall in $\mathrm{FEV}_{1.0}$ of less than 0.06 litres is considered as 'no

Table 2 Relationship of byssinosis (all grades) to smoking habit and duration of exposure to sisal dust for workers in the brushing department

\begin{tabular}{|c|c|c|c|c|c|c|}
\hline Smoking habit & $\begin{array}{l}\text { Length } \\
0-9 \text { yr } \\
\text { No. }\end{array}$ & $\begin{array}{l}\text { re to sisal dus } \\
\%(n=33)\end{array}$ & $\begin{array}{l}\text { orker } \\
10-1 \\
\text { No. }\end{array}$ & $\%(n=38)$ & $\begin{array}{l}20+y r \\
\text { No. }\end{array}$ & $\%(n=12)$ \\
\hline Total & 10 & 30 & 21 & 55 & 9 & 75 \\
\hline
\end{tabular}

Table $3 F V C$ and FEV $V_{1 \cdot 0}$ pre-shift and after-shift values in litres (mean $\pm S D$ ) together with acute changes during shift (\%) for workers without byssinosis in spinning and brushing, and with byssinosis grade $\frac{1}{2}+I$ and grade II in brushing

\begin{tabular}{|c|c|c|c|c|c|c|c|c|c|}
\hline Group & No. of workers & $\begin{array}{l}\text { FVC } \\
\text { Pre-shift }\end{array}$ & After-shift & $\begin{array}{l}F V C \\
\%\end{array}$ & $\boldsymbol{P}$ & $\begin{array}{l}F E V_{1 \cdot 0} \\
\text { Pre-shift }\end{array}$ & After-shift & $\underset{\%}{F E V_{1.0}}$ & $P$ \\
\hline $\begin{array}{l}\text { Without byssinos } \\
\text { Spinning } \\
\text { Brushing }\end{array}$ & $\begin{array}{l}62 \\
30\end{array}$ & $\begin{array}{l}3.71 \pm 0.37 \\
3.56 \pm 0.5\end{array}$ & $\begin{array}{l}3.65 \pm 0.38 \\
3.48 \pm 0.47\end{array}$ & $\begin{array}{l}-1 \cdot 6 \\
-2 \cdot 2\end{array}$ & $\begin{array}{l}\text { NS } \\
\text { NS }\end{array}$ & $\begin{array}{l}3.05 \pm 0.44 \\
2.93 \pm 0.46\end{array}$ & $\begin{array}{l}3.0 \pm 0.45 \\
2.87 \pm 0.44\end{array}$ & $\begin{array}{l}-1 \cdot 6 \\
-2\end{array}$ & $\begin{array}{l}\text { NS } \\
\text { NS }\end{array}$ \\
\hline $\begin{array}{l}\text { With byssinosis } \\
\text { Grade } \frac{1}{2}+\text { I } \\
\text { Grade II }\end{array}$ & $\begin{array}{l}18 \\
20\end{array}$ & $\begin{array}{l}3.665 \pm 0.41 \\
3.40 \pm 0.51\end{array}$ & $\begin{array}{l}3.51 \pm 0.41 \\
3.175 \pm 0.54\end{array}$ & $\begin{array}{l}-3 \cdot 1 \\
-6\end{array}$ & $\begin{array}{l}\text { NS } \\
\text { NS }\end{array}$ & $\begin{array}{l}3.04 \pm 0.36 \\
2.76 \pm 0.37\end{array}$ & $\begin{array}{l}2.93 \pm 0.41 \\
2.34 \pm 0.36\end{array}$ & $\begin{array}{c}-3 \cdot 6 \\
15\end{array}$ & $\begin{array}{l}\text { NS } \\
P<0.05\end{array}$ \\
\hline
\end{tabular}


Table 4 Acute changes in FEV $V_{1 \cdot 0}$ during the shift graded* as no acute effect (a drop of less than 0.06 litres), slight acute effect ( $a$ drop between 0.06 and 0.2 litres) and definite acute effect (a drop of more than 0.2 litres) in spinning and brushing workers without byssinosis, and in brushing workers with byssinosis grade $\frac{1}{2}+I$ and II. The number of workers and their \% of the total is shown for each grade of acute change

\begin{tabular}{|c|c|c|c|c|c|c|c|}
\hline \multirow[t]{2}{*}{ Group } & \multirow[t]{2}{*}{ Total no. of workers } & \multicolumn{6}{|c|}{ Workers with a fall in $F E V_{1 \cdot 0}$ during the shift } \\
\hline & & No. & $\%$ & No. & $\%$ & No. & $\%$ \\
\hline \multicolumn{8}{|c|}{ Without byssinosis } \\
\hline Spinning & 62 & 38 & 61 & 18 & 29 & 6 & 10 \\
\hline Brushing & 30 & 18 & 60 & 2 & 7 & 10 & 33 \\
\hline \multicolumn{8}{|l|}{ With byssinosis } \\
\hline Grade $\frac{1}{2}+I$ & 18 & 10 & 56 & 2 & 11 & 6 & 33 \\
\hline Grade II & 20 & 3 & 15 & 2 & 10 & 15 & 75 \\
\hline
\end{tabular}

*Grading according to Bouhuys et al. (1970)

acute effect', between $\mathbf{0 . 0 6}$ and $\mathbf{0 . 2}$ litres 'slight acute effect' and more than 0.2 litres 'definite acute effect'. This analysis shows that the symptoms of byssinosis correlate well with acute changes in $\mathrm{FEV}_{1.0} ; 75 \%$ of the workers with grade II byssinosis had a definite acute effect compared with $33 \%$ of workers with grade $\frac{1}{2}+I$ byssinosis and $10 \%$ of workers without byssinosis in spinning. On the other hand only $15 \%$ of the workers with grade II byssinosis showed no acute effect compared with about $60 \%$ in every other group. However in the same table it can be seen that in $33 \%$ of the workers in the brushing department who denied symptoms of byssinosis a definite acute effect on FEV .0 could be demonstrated.

In Table 5 the chronic changes in ventilatory function (when the workers had spent two days away from work and dust) are shown. Workers with $\mathrm{FEV}_{1.0}$ greater than $80 \%$ of the predicted value are considered to have no chronic ventilatory impairment, those with $\mathrm{FEV}_{1.0}$ between 80 to $60 \%$ of that predicted to have slight to moderate impairment and those with $\mathrm{FEV}_{1.0}$ less than $60 \%$ to have moderate to severe impairment (Bouhuys et al., 1970). Only two workers with grade II byssinosis $(10 \%)$ had moderate to severe chronic ventilatory function impairment and between 6-16\% of the workers in all the groups showed slight to moderate impairment.

\section{CLINICAL EXAMINATION}

On clinical examination three workers were found to have bronchial asthma, present since childhood in all of them. Four workers in the brushing department had signs of lung fibrosis and were referred to hospital for $x$-ray and sputum examination.

\section{Discussion}

This investigation is, as far as is known, the first to show definitely that the symptoms of classical byssinosis occur among sisal workers. A high prevalence of byssinosis was found among workers in the brushing departments. The only previous study of a sisal brushing factory (Stott, 1958) did not investigate symptoms of byssinosis. The

Table 5 Chronic changes in FEV ${ }_{1.0}$ graded $^{*}$ as no chronic ventilatory impairment $\left(F E V_{1.0}\right.$ greater than $80 \%$ of the predicted value), slight to moderate chronic ventilatory impairment (FEV $V_{1 \cdot 0}$ between 60 and $80 \%$ of the predicted value) and moderate to severe ventilatory impairment (FEV $V_{1 \cdot 0}$ less than $60 \%$ of the predicted value) in spinning and brushing workers without byssinosis, and in brushing workers with byssinosis grade $\frac{1}{2}+I$ and II. The number of workers and their $\%$ of total is shown for each grade of chronic ventilatory impairment

\begin{tabular}{|c|c|c|c|c|c|c|c|}
\hline $\begin{array}{l}\text { Group } \\
\text { Without byssinosis }\end{array}$ & Total no. of workers & \multicolumn{2}{|c|}{$\begin{array}{l}\text { Workers with FEV } V_{1 \cdot 0} \\
>80 \% \text { of predicted } \\
\text { No. } \quad \%\end{array}$} & \multicolumn{2}{|c|}{$\begin{array}{l}60-80 \% \text { of predicted } \\
\text { No. } \%\end{array}$} & \multicolumn{2}{|c|}{$\begin{array}{l}<60 \% \text { of predicted } \\
\text { No. } \quad \%\end{array}$} \\
\hline $\begin{array}{l}\text { Without byssino } \\
\text { Spinning } \\
\text { Brushing }\end{array}$ & $\begin{array}{l}62 \\
32\end{array}$ & $\begin{array}{l}57 \\
27\end{array}$ & $\begin{array}{l}92 \\
84\end{array}$ & $\begin{array}{l}5 \\
5\end{array}$ & $\begin{array}{r}8 \\
16\end{array}$ & - & - \\
\hline $\begin{array}{l}\text { With byssinosis } \\
\text { Grade } \frac{1}{2}+\text { I } \\
\text { Grade II }\end{array}$ & $\begin{array}{l}18 \\
20\end{array}$ & $\begin{array}{l}17 \\
15\end{array}$ & $\begin{array}{l}94 \\
75\end{array}$ & $\begin{array}{l}1 \\
3\end{array}$ & $\begin{array}{c}6 \\
15\end{array}$ & $\overrightarrow{2}$ & $\overline{10}$ \\
\hline
\end{tabular}

*Grading according to Bouhuys et al. (1970). 
results of our study confirm the evidence of previous workers that there is low risk of byssinosis in sisal spinning departments (Gilson et al., 1962; Munt et al., 1965; McKerrow et al., 1965).

In explaining the difference in prevalence of byssinosis between spinning and brushing departments we are limited by the fact that we were unable to measure the dust concentration because dust samplers were not available. Gilson et al. (1962) measured dust concentrations in a Kenyan sisal spinning department and found the levels to be $0,4.48$, and $1.57 \mathrm{mg} / \mathrm{m}^{3}$ for coarse, medium and fine fractions respectively. They estimated the total dust concentration to be more than three times as high as the average total dust concentration in the card rooms of cotton mills in Lancashire. Stott (1958) measured the dust concentration (count of particles $/ \mathrm{mm}^{3}$ ) in a sisal brushing department in Kenya and found it to be six times greater than that in a sisal spinning department. This was certainly our impression. Moreover the workers in the brushing department handfeed the machines. As the mean duration of exposure is significantly higher in brushing compared with that in spinning (Table 1), it may be assumed that the time-weighted dust measurement is far greater in brushing compared with that in spinning. This measurement was found to be highly correlated with the prevalence of byssinosis in cotton workers (Fox et al., 1973; Khogali, 1976).

The causative agent of byssinosis is not fully known (Nicholls, 1962; Nicholls and Skidmore, 1975). Whatever the nature of this substance, our results suggest that it is present in sisal dust although possibly in low concentrations; therefore prolonged exposure is necessary before symptoms of byssinosis develop. From Table 2 it can be seen that, in the brushing department, for any duration of exposure the smokers had a higher prevalence of byssinosis than non- or ex-smokers. This is in agreement with the finding of Berry et al. (1974) in Lancashire cotton mills.

In sisal workers there is a strong association between byssinosis and acute changes in FVC and FEV $_{1.0}$ similar to those observed in cotton workers (Žuškin et al., 1975). The largest decreases in FVC and FEV $_{1.0}$ before the shift and during dust exposure occurred in those with grade II byssinosis (Table 3). However, some workers without byssinosis had falls of more than $\mathbf{0 . 2}$ litres in $\mathrm{FEV}_{\mathbf{1} \cdot \mathbf{0}}$ during the shift (Table 4).

The prevalence of chronic cough and chronic bronchitis was found to be low in sisal workers. The highest was among workers in the brushing departments, of whom $9 \%$ had chronic cough and $12 \%$ had chronic bronchitis (Table 1 ). We did not compare this with their prevalence in a control group so we cannot say whether sisal dust played a part in the pathogenesis of chronic bronchitis. The low prevalence of chronic cough and chronic bronchitis is comparable to that in Sudanese ginnery workers (Khogali, 1976) and can be explained in these African workers similarly by their moderate smoking habits, as $90 \%$ of workers in both series smoked less than 10 cigarettes/day, and also by the low atmospheric pollution outside the factories.

We are greatly indebted to the Management, Workers' Committee, workers and medical officers of all the sisal factories in Tanga region, and to the Tanga Regional Health Officer without whose co-operation this investigation could not have been made. We would like to thank Dr E. Tarimo, Director of Preventive Health Services in the Tanzanian Ministry of Health for his support for this work. We are grateful to $\mathrm{Dr}$ M. Khogali, for his criticism of this manuscript. Dr K. Y. Mustafa would like to acknowledge the support of the World Health Organization for the African Region.

\section{References}

Berry, G., Molyneux, M. K. B., and Tombleson, J. B. L. (1974). Relationships between dust level and byssinosis and bronchitis in Lancashire cotton mills. British Journal of Industrial Medicine, 31, 18-27.

Bouhuys, A., Barbero, A., Lindell, S. E., Roach, S. A., and Schilling, R. S. F. (1967). Byssinosis in hemp workers. Archives of Environmental Health, 14, 533-544.

Bouhuys, A., Gilson, J. C., and Schilling, R. S. F. (1970). Byssinosis in the textile industry. Archives of Environmental Health, 21, 475-478.

El Batawi, M. A., Schilling, R. S. F., Valić, F., and Walford, J. (1964). Byssinosis in the Egyptian cotton industry: changes in ventilatory capacity during the day. British Journal of Industrial Medicine, 21, 13-19.

Fox, A. J., Tombleson, J. B. L., Watt, A., and Wilkie, A. G. (1973). A survey of respiratory disease in cotton operatives. Part 1. Symptoms and ventilation test results. British Journal of Industrial Medicine, 30, 42-47.

Gandevia, B., and Milne, J. (1965). Ventilatory capacity on exposure to jute and the relevance of productive cough and smoking to the response. British Journal of Industrial Medicine, 22, 187-195.

Gilson, J. C., Stott, H., Hopwood, B. E. C., Roach, S. A., McKerrow, C. B., and Schilling, R. S. F. (1962). The acute effect on ventilatory capacity of dusts in cotton ginneries, cotton, sisal and jute mills. British Journal of Industrial Medicine, 18, 9-18.

Khogali, M. (1969). Population study in cotton ginnery workers in the Sudan. British Journal of Industrial Medicine, 26, 308-313.

Khogali, M. (1976). Byssinosis: a follow-up study in cotton ginnery workers in the Sudan. British Journal of Industrial Medicine, 33, 166-174.

Lammers, B., Schilling, R. S. F., and Walford, J. (1964). A study of byssinosis, chronic respiratory symptoms and ventilatory capacity in English and Dutch cotton workers 
with special reference to atmospheric pollution. British Journal of Industrial Medicine, 21, 124-134.

Mair, A., Smith, D. H., Wilson, W. A., and Lockhart, W. (1960). Dust diseases in Dundee textile workers. British Journal of Industrial Medicine, 17, 272-278.

McKerrow, C. B., Gilson, J. C., Schilling, R. S. F., and Skidmore, J. W. (1965). Respiratory function and symptoms in rope workers. British Journal of Industrial Medicine, 22, 204-209.

Medical Research Council (1960). Standardised questionnaires on respiratory symptoms. British Medical Journal, 2, 1665 .

Munt, D. F., Gauvain, S., Walford, J., and Schilling, R. S. F. (1965). Study of respiratory symptoms and ventilatory capacity among rope workers. British Journal of Industrial Medicine, 22, 196-203.

Mustafa, K. Y. (1977). Spirometric lung function tests in normal men of African ethnic origin. American Review of Respiratory Diseases, 116, 209-213.

Nicholls, P. J. (1962). Some pharmacological actions of cotton dust and other vegetable dusts. British Journal of Industrial Medicine, 19, 23-41.

Nicholls, P. J., and Skidmore, J. W. (1975). Comparative study of the smooth muscle contractor activity of airborne dust and of dustiness in cotton, flax and jute mills. British Journal of Industrial Medicine, 32, 289-296.

Roach, S. A., and Schilling, R. S. F. (1960). A clinical and environmental study of byssinosis in the Lancashire cotton industry. British Journal of Industrial Medicine, 17, 1-9.

Schilling, R. S. F. (1956). Byssinosis in cotton and other textile workers. Lancet, 2, 261-265.

Smiley, O. (1961). Background to byssinosis in Ulster. British Journal of Industrial Medicine, 18, 1-9.

Stott, H. (1958). Pulmonary disease amongst sisal workers. British Journal of Industrial Medicine, 15, 23-37.

Žuškin, E., Valić, F., Butković, O., and Bouhuys, A. (1975). Lung function in textile workers. British Journal of Industrial Medicine, 32, 283-288. 